\title{
北スマトラにおける港市国家と後背地
}

\author{
弘末 雅士 \\ I はじめに—— 問題の所在 —
}

東西海洋交易路の要衝マラッカ海峡と東海岸を接し, 西海岸において西方世界を結 ぶインド洋と接するスマトラ島は，古くから国際海洋交易活動に関与してきた。こう した交易活動は，スマトラ島の河川河口付近に中継交易に携わる港市を成立させた。 シュリーヴィシャャの中核的港市であったパレンバンやジャンビ, 北スマトラのフ ル，パサイ，ランブリ，アチェ，西海岸のバルス等は，その代表的なものである。

これらの港市の後背地は, 熱帯降雨林気候のもたらす豊かな降雨によって形成され た森林や河川盆地を有した。内陸部で産出された竜脳, 安息香, 沈香, 蜜蠟等の森林 生産物や，金，鉄，鉛等の鉱産物は港市に搬出され，スマトラの重要な輸出品となっ た [Wolters，1967 : 95-127；Miksic，1980：46-47]。その他, 後背地は米や家畜等 の食糧をも港市に搬出した。見返りとして後背地側は, 塩や干魚等の海産物や綿布を 得たのである。

こうした港市と後背地との関係は，15世紀以降東西交易活動が活性化するにつれ， より強化された。15-17世紀の東南アジア海洋世界が繁栄した時期や，18世紀終りか ら19世紀後半に至るペナンンシンガポールを中心とする交易圈の活動が活発になった 時期，スマトラ島の交易活動も活性化した。この時期，上述した森林生産物や鉱産物 の他, 胡椒, ガンビール, タバコ, コーヒー等が重要な商品となり, 内陸部から港市 にもたらされた [Anderson, 1971:191-357；Dobbin, 1983:91-95]。輸入品も, 上 述した海産物や綿布の他，金属製品やアヘン（18世紀以降）が加わった。

本稿は，こらしたスマトラ島に和ける交易活動の活性化が，港市・後背地の相互的 関係の強化をむたらし, 沿岸部における港市の隆盛に対応して, 内陸部に生産交易活 動を司る権威が形成されたことを説明したい。従来，この時期の交易活動の隆盛が， 港市の繁栄をもたらし, 港市の影響力が一層後背地に及び, 文化的にも前者が後者を 繰り込んでいくことが，しばしば指摘されてきた [Reid, $1980: 240 ;$ Hall, 1985 ： 
東南アジアー歴史と文化一 No. 22, 1993

258-260 ; Milner, $1982: 84-93]$ 。港市は, 後背地からの産物の一層の搬出を目指す ため, 内陸部之のネットワークの強化につとめた。後背地の人々の生活必需品をもた らす港市支配者に対する尊崇の念は強く, 産地と港市との関係は, 一般にオランダ植 民地支配が確立する19世紀後半から20世紀初めまで維持された。ところで後背地側 は, 産物の搬出の一方で, 自らの生産活動を維持することが必要となっていた。港市 の支配権力はこの時期㧪張したが，港市が沿岸部から離れた内陸部にまで食糧を供給 することでその活動を保障することは，かなり困難なことであった。この意味におい て, 港市と後背地との関係を, 前者の後者に対する一元的な関係でのみ理解すること に疑問が生じてくる。

本稿は, 北スマトラに例をとり, 港市の隆盛が, 内陸部に交易活動をささえる農耕 を司る神聖王の権威を成立させたことを説明する。これにより，港市と後背地との関 係の強化が, 沿岸部のマレー化に対応して, しばしば後背地に海岸部とは異なる文化 的社会を形成せしめることを明らかにしたい。

\section{II 北スマトラにおける港市と後背地}

内陸部に森林生産物や鉱産物の産地を有する北スマトラは, 古くから国際海洋交易 活動の舞台の一つとなった。バルス, ランブリ, アル等は, こらした産物の輸出港と して栄えた。また $14 \cdot 15$ 世紀以降, パサイやアチェにおいて胡椒栽培が始まると, 多 くの西方世界からの商人を引きつけた。

北スマトラの港市と後背地は, 河川ルートや河川沿いの陸上ルート, 山岳尾根ルー トを通じて，多様に結びついていた。北スマトラは，ブキット=バリサン山脈が東西 両岸に迫っているため, 河川の航行は海岸部付近に限られた。より内陸部との交通 は, 河川沿いの陸上ルートと尾根沿いの山岳ルートを通して主になされた。山岳ルー トは, 部分的に険しい山岳丘陵を通過せねばならなかったが，一旦尾根筋に至るとその 通行は比較的円滑となり，これを用いて東西両海岸間の交易が可能となった。1510年 代前半にスマトラ島を訪れたトメンピレスは，スマトラ東岸に存在したアル王国の商 人が西岸のバルスに赴いたことや，西岸のシンケル (Singkel), バルスに東岸のペデ ィール (Pedir) やパサイの商人がやって来ていることを記している [Pires, 1966 : 274,290]。こ5した東西両岸を結ぶルートがいつ形成されたのか, 定かなことはわか らないが, 北スマトラが古くから竜脳の産地として知られ, 11・12世紀にかけて多数 のタミル人商人の来航を招き, 東岸内陸部のカロ(Karo)高原に居住するカロ = バ y ク族の中に南インド系の名称を有する氏族が存在し [Joustra, $1902:$ 554-556 ; Kern, 
北スマトラに括ける港市国家上後背地

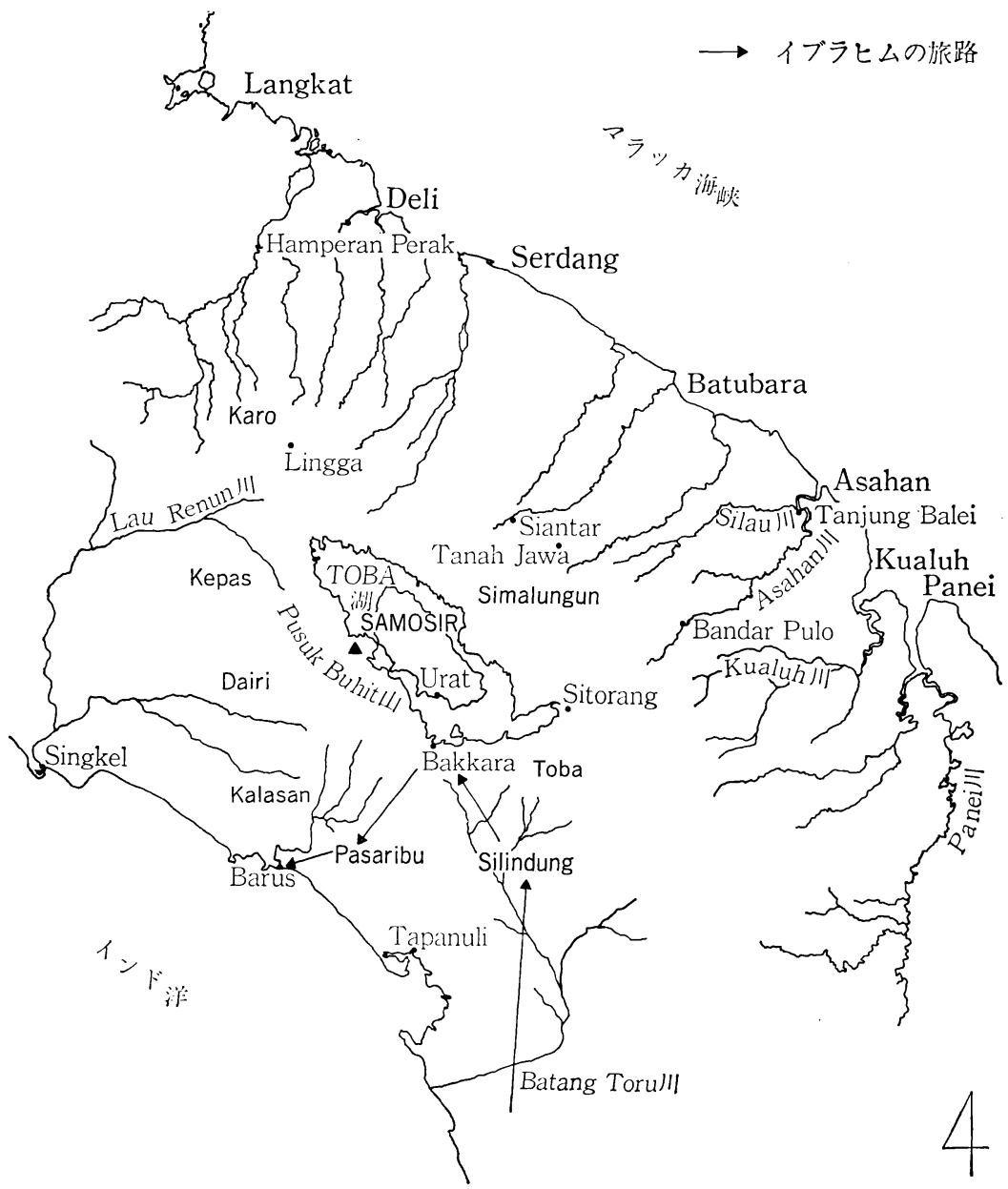

図1 ペタック地区と周辺港市

$1903:$ 358-361]，彼らが西岸の後背地からやって来たといら伝承を有する [Neumann, 1926 : 16-27 ; Tideman, $1936: 28-30]$ こと等を考虑すると, 11・12世紀頃か ら序々に形成されたものと考えられる。また，こらした内陸交易ルートがその後も活 用されていたことが，1823年にスマトラ東岸を訪れたアンダーソンの記録にもらかが える [Anderson, $1971: 39-52]$ 。 
東南アジアー歴史と文化一 No. 22, 1993

こうした広範な交易ルートは, 港市と後背地とのネットワークの存在を基盤とした ものである。港市はその成立基盤として産品をもたらす後背地を必要としたし, 後背 地も生活必需品の塩や綿布をもたらす港市を必要とした。14・15世紀の北スマトラで 最も繁栄する港市となったパサイの建国由来を語るヒカヤット =ラジャニラジャーパ サイ (Hikayat Raja-Raja Pasai : 『パサイ列王伝』) は，初代の王となるメランシル (Merah Silu) が内陸部に赴き, 自らの存在の正当性を認めさせた上で, 港市国家を 建国したことを伝えている [Hill, 1960 : 53-54, 114-115 ; Hall, 1977 : 223-227]。

こうした港市と後背地との相互的関係は, 交易活動が活発化してくると, 港市の隆 盛を招くとともに, 内陸部の生産交易活動を統轄する後背地側の権威を必要とするこ ととなった。北スマトラの沿岸部におけるパサイ, アル, バルスの隆盛は, 同時に内 陸部におけるバタックの権威さらにはミナンカバウの権威を擡頭させた。メンデス = ピントやピレスの記述によれば，上述した港市国家の内陸部にバタ（バタック）王 [ナグール Nagur 国王] が存在し, 後背地に勢力を確立していたことを示している [Pinto, 1979 : 37-52 ; Pires, 1966 : 272-273]。またバルスやアルは内陸部でミナン カバウと接触を有したことが記されている。これらの港市で別かれる商品の多くが, 竜脳や安息香, 生系, 毬, 蜜蠟, 樹脂等の森林生産物や金, 米や家畜であったこと は, 内陸部の生産交易を司る権威の重要性を示している。

16世紀になりアチェが勢力を払大し始めると，まずアチェはパサイやバルス，ア ル等の港市を影響下に置いた。そして、これらの港市と関係を有した内陸部のバタッ ク地区にも介入を開始した。ピントの記述に見られる，バタック王アンジェシリニテ ィモラジ+ (Angeessiry Timorraja) とアチェとの抗争はこの一端を語るものと言 えよ5 [Pinto, $1979:$ 37-56]。やがて軍事力に優るアチェは,ナグールを解体させ, 代って内陸部のカロ地区, シマルングン (Simalungun) 地区を影響下に置いた [Tideman, $1922: 36-38]$ 。

が，こらして勢力を確立したアチェも，常時内陸部に権限を行使することは困難で あった。ましてや，内陸部の食糧を安定供給する仕組を作ることで輸出用作物の生産 を保障することはほとんど出来なかった。首都バンダニアチェに多大な人口をかか え, 周辺部で胡椒栽培を展開していたアチェは, 食糧をほとんど輸入に頼る状態であ ク，インドやスマトラ東岸のデリ（Deli）より購入したのであった [Ito, $1982: 34-$ 39]。この点はまたバルスについても言えることであった。バルスは, マラッカが1511 年ポルトガルに占領されて以降スマトラ西岸からスンダ海峡を通るルートが西方イス ラム商人によって利用され始めると，繁栄する港となったが，この港市も食糧をニア 
北スマトラにおける港市国家と後背地

スや後背地のトバ (Toba) 地区より輸入しており [Kroeskamp, 1931 : 150 ; Broch Onz 93=542], 余剰を内陸部の産地に送ることは困難な状態であった。これら港市に とって, 後背地の生産活動を保障する権威が必要であったのである。

以上が，15-17世紀の北スマトラの置かれていた状況であった。

\section{III バルスの隆盛と後背地}

15一-17世紀の北スマトラの港市と後背地との関係を考察する上で，バルスと内陸部 との関係は貴重な材料を提供してくれる。バルスは，古くから（遅くとも9世紀より） 良質の竜脳や安息香を輸出した港として知られ，16・17世紀に繁栄の時期を迎え，こ の時期の港市と後背地との関係の一つの代表的な事例を示していると思われるからで ある。

スマトラ西海岸のシンケルからバルスにかけての内陸部は, 竜脳の産地を有し, バ ルスからバタン =トル (Batang Toru) 川にかけての後背地は, 安息香を産出した [van Vuuren, 1908: 1389-1395]。これらの森林生産物を求めて, アラブ人やペルシ ア人らがこの地に来航していたことが，9世紀以降のアラビア語史料より明らかとな る [Drakard $1989: 61-65]$ 。またバルス近郊のロブ=トア（Lobu Tua）で発見され た碑文には，1088年にこの地に1500名のタミル人商人が存在したことが記されている [Sastri，1932 : 314-327]。その後14世紀にミナンカバゥのパガルルニン (Pagarruyung) 王朝の勢力が拡大すると,バルスはまたミナンカバウの金の輸出港とすなった。 16世紀になるとバルスは繁栄の時期を迎えた。1510年代前半にこの地を訪れたピレ スは以下の如く記述している [Pires, $1966: 288$ 。

この王国はソモトラ全島の品物の取引の中心地である。というのは，ここは黄 金, 生糸, 安息香, 大量の竜脳, 蘆蕒, 蜜侅, 蜂蜜およびその他の品物が通過 する中継港で，そのためにこの王国は今までに述べたどの王国よりも豊かであ る。ソモトラ島ではバルス,ティコ，ピラマンの安息香は量が多く，色がたいへ ん白い。ここに述べた三つの王国，すなわちパンシュール（バルスの別名：引用 者), ティコ,ピラマンはメナンカボの要衝である。それはこの [三国の国王が] 互いに親戚関係にあり，またこれらの王国が海岸を支配し，グザラテ人は毎年こ こに来て，大きな取引をするので，商品はすべてこれらの王国に集められ，ここ で上記のグザラテ人と取引をするからである。毎年一隻あるいは二, 三隻の船が 来て, 衣服をすべて売り別く。そして多量の黄金, 生系, たくさんの安息香, 沈 香, 二種類の竜脳——その多くは食用である——, 多量の蜜蠟, 蜂蜜を集める。 
東南フシアー歴史と文化一 No. 22, 1993

グザラテ人は商品をすべて処分する。

バルスで別かれた黄金については，ピレスは別の筒所でミナンカバゥより産出され たものであると述べている [Ibid. 291]。その他の森林生産物は, バルスの後背地で産 出されるものであり, それらを搬出したのは, 内陸部に居住するオーストロネシア系 の一種族バタック族である。安息香は，一般に千メートル以上の山岳地帯に生育する 原木の樹脂を加工して得られるものである [吉田 1971:426-438]。これは自生のも のからと栽培木からの採集が可能で, 17世紀後半にオランダ東インド会社が来航した 時には既にその栽培が行なわれていた［VOC 1272 : 1077 ; Drakard, $1990: 34$ ]。一 方竜脳木も山岳地帯に自生したが，その栽培は難しく，当時は原木を捜し，その樹脂 を採集する方法のみが行なわれていた。バタック族にとって良質の竜脳を見出すには 日時と技術を要し，そのための儀礼と特殊言語が存在した [de Ligny, $1923: 549-$ 555]。

ピレスが訪れた後，バルスは間もなく（遅くとも1539年までには）アチェの影響下 に入り，アチェのスルタンはこの地に代官（panglima）を任命した。その後17低紀後 半には，オランダ東インド会社がこの地に商館を設け，バルスの支配者を介して1778 年まで産物の独占取引を試みた [Drakard, $1990: 27-41]$ 。

こらした森林生産物の輸出港バルスは, 古くからバタック族の重要な外部世界との 接触口であり，彼らの世界観の中でも重要な位置を占めることとなった。

バルスと後背地のトバ湖との間に居住するトバニバタック族の始祖伝説は, バルス をバタック族誕生の聖山プスックニブヒット（Pusuk Buhit）と結びつけている。そ れによれば, 最初の人類はトバ湖畔のプスックンブヒット山に天孫降臨した神々の子 孫であるとい5 [Hoetagaloeng, $1926: 15-30$; Ypes, $1932: 24-27$ ]。バタック族の 至高神であるムラジャディニナ=ボロン (Mulajadi Na Bolon) の息子バタラ =グル の娘シニボルデアックパルジャル (Si Borudeakparujar) は, 天界を去り, 地上界に 降臨し地上世界の創造を始めた。彼女は同じく天界より降臨したラジャニオダプオダ プ (Raja Odapodap) と結婚し，両者の間に誕生した娘と息子との更なる結婚によ り, 最初の人類が硟生した。彼らは, プスックンブヒット山のふもとのシアンジュル ムラムラ (Sianjurmulamula) に居住していたという。そして, 最初の人類から 5 代 目に最初のバタック人, シニラジャニバタック（Si Raja Batak）が誕生した。彼 には, グルニタテアブーラン (Guru Tateabulan) とラシャャニイスンバオン (Raja Isumbaon）の 2 人の息子があった。グルニタテアブーランには 9 人の息子があった が，その長男のラジャニビアクビアク（Raja Biakbiak）は生まれたとき，手足がな 
北スマトラにおける港市国家と後背地

かったといら。ムラジャディニナニボロン神は, 彼に手足と翼と豚の顔を与えた。す るとラジャ =ビアクビアクは, 西岸のバルスに飛び去り, 以来ラジャ=ウティ (Raja Uti : “Magical King” の意）と呼ばれるようになった(1)。トバニバタック族は，ラ ジャニウティがバルスの沖の小島の「聖なる外界」(tano jau puti) に住んでおり， 至高神より聖なる力を授けられ不老不死であるとみなした。トバンバック族の中に は, 彼らの祖先と近縁関係を有するラジャニウティに貢物（馬）を奉納するため, 定 期的にバルスを訪れる慣行が20世紀始めまで存在した [Ypes, $1932: 423-424$; Vergouwen, $1932:$ 551-552]。このラジャ=ビフクビフクのいたプスック=ブヒット山 は，バタック世界の中心であり，かつ外界とを絡ぐ聖なる山であった。

シアンジュルムラムラは, この山のふもとの河川渓谷が形成する盆地であり, 内陸 部の中央部に位置するトバ湖に近接した。トバニバタック族の伝承によれば，これ以 降人々は周辺の地域に拡散して行ったという。現在バタック族は, 通常方言別に, ト バ,カロ, ダイリ (Dairi), シマルングン, アンュラ (Angkola), マンダィリン (Mandailing) の 6 つの支族に分けられる [Bataks, $1917: 177$; Lebar, $1972: 20$ ]。 言語的には，(1)カロ，ダイリ (2)トバ, アンコラ, マンダィリンの 2 つのグループに 大別でき，シマルングンは，(1)と(2)の中間に位置している [Voorhoeve, $1955: 9$ ]。 ダイリ族やシマルングン族の伝承によれば，彼らの多くはトバ地区をその出身地とし ている [Ypes, $1907: 475$; Tideman, $1922:$ 53-68]。またカ口族の5ちには，ダイ リ地区より移住して来た伝承を有する氏族がいくつか存在する [Neumann, 1926 : $32-34]$ ( 2 )。

16・17世紀のバルスの繁栄は，この港町と後背地との関係をより強固にするととも に, 内陸部に生産交易活動を支劣権威を摆頭させた。ピレスが訪れた後, バルスは 間もなくアチェの影響下に入った。この頃苂スに, 上バルス (Barus Hulu) 王家 と下バルス (Barus Hilir) 王家の二王家が成立していた可能性が高い(3)。後に1660 年代にオランダ東インド会社が来航した時には, 既に二王家が存在し, それぞれが後 背地とのネットワークを形成していた [Kroeskamp, 1931 : 152-153; Macleod, 1905 : 470]。両王家に伝わる年代記は，この両家が内陸部のバタック地区と特別な関係を 樹立した後, バルスにやって来たことを語っている(4)。とりわけ下バルス王家の年 代記は, 初代の下バルス王がバタック族のラジャニウティ信仰を基盤に後背地と緊密 な関係を形成し，トバ湖畔の稲作地帯に王の代理を設けたことを語っている。

それによれば，初代の下バルス王となるスルタンニイブラヒム（Sultan Ibrahim) は, 故鄉タルサン (Tarusan : バルスより $400 \mathrm{~km}$ 程南のミナンカバゥ地区西岸の港 
東南アジー歴史と文化一 No. 22, 1993

市）を離れバルスにやって来る前に, 内陸部のトバニバタック地区に赴き, 数カ所に 滞在したという [Tambo, $1872: 9-16$; Drakard, 1988 : 194-202]。スルタンニイフ ラヒムは，パガルルユン王朝の血統を引くと称する父タルサン王と不和になり，1000 名の臣下とともに故郷を後にした。彼は新たに住むべき土地を求めて西海岸を北上し 始めた。道中の到達した河口で, 彼は持参した故郷の水と重さを比べてみた。たが, いずこの地も重さが足りなかった。バタンニトル川河口付近までやって来たとき，イ ブラヒムは神の意向に従い, 旅の方向を内陸部へ变えた。このバタン ルトル河口の 内陸部は, 安息香の産地であったのである。

最初にイブラヒム一行が到着したのは, トバのシリンドゥン (Silindung) であっ た。イブラヒムは, シリンドゥンの人々全員から丁重に迎光られ，人々よりシリンド ゥンの王（raja）になってくれるよう切望されたという。しかしイブラヒムは，持参 した水と同じ重さの地にまだ至っていないためこれを断り，彼に代って人々を統べる ため「四代官」(Panghulu Empat) を任命した。そして人々に，イブラヒム及び彼 の子々係々に至るまで尊崇するよう約束させ，四代官には馬を彼のもとに奉納するよ ら命じそその地を後にした。

次に立寄ったのは，トバ湖畔のバッカラ(Bakkara) の地であった。一行がバッカ ラの一村落にやって来たとき，村人は「どちらの地から拈いでになり，どちらの国へ 行かれるのか, どちらの村にいらっしゃったのか，何の目的でこちらに来られたの か」と尋ねた [Tambo, 1872: 10 ; Drakard, 1988；196]。イブラヒムはしかし，村 人の言葉が理解できず，「我々は千（seribu）人の男女をつれて旅をしている」とだけ 答えた。すると村人は，「そらであるならば，貴方様の氏族はパッサリブ(Pasribu)で す。我々もパッサリブ氏族です。それならば貴方様はこの地にお住まいになり，我々 の王になっていたたくことができます」と語った。またバッカラの首長達も皆, イブ ラヒムにその地の王となってもららことを希望した。これに対しイブラヒムは, 人々 がイスラム教に改宗すれば，自分もここに居住すると答えた。首長達は，イブラヒム の他のいかなる命にも従らが，イスラム教に改宗することだけは容赦してくれるよう 懇願した。イブラヒムは了解し, 彼の住むためのモスクを建てさせた。彼はバッカラ の一首長の娘と結婚し, 彼女をイスラム教に改宗させた。しばらくの間, イブラヒム はバッカラに滞在した。

しかし，彼の持参した水とその地の水とが同じ重さでないので，イブラヒムは旅を 続けねばならなかった。イブラヒムはバッカラの首長達を呼び，彼は旅を続けねばな らないので, 彼に代わり, 間むなく生まれるであろら彼の子供をシンガ=マハラジャ 
(Singa Maharaja「獅子大王」)(5)と名付け，その子にバタックの地を統治させるこ とを約束させた。そして将来イブラヒムが造る町に馬を奉納に来るよう命じた。 やがてイブラヒムの予告通り，バッカラに残した妻から一人の男子が生まれた。そ の子の誕生するとき, 地震が起き, 豪雨となり, 雷が鳴り, 大騒ぎとなった。人々は 未だかつてない事態に，大いに驚いた。イブラヒムの命令どおり，人々はその子をシ ンガニマハラジャと名付けた。その子は，ハッッラの王となり，バタック族を統治す ることとなった。

一方イブラヒムは, ハッカラを去った後, 西海岸に近接する内陸部のパッサリブに やって来た。その地の首長もバッカラと同様に,イブラヒム一行がどこから来，どこ へ行こうとしているのか，何をしにこの地にやって来たのか尋ねた。イブラヒムは, 「自分の国はバッカラで，氏族はパッサリブ」と答えた [Tambo，1872:14；Drakard, 1988 : 199]。その地の首長は，それならば自分達も同じ氏族であるので，そこ に滞在してよい旨を告げた。滞在中イブラヒムは，パッサリブニドロック (Pasaribu Dolok) の地にオナンニシバトゥバトゥ(Onan Sibatubatu) という市場を設け，そこ まではどのトバ族も商品を持って来てよいが，それから先は，パッサリブの四氏族 (Matondang, Talihoran, Bondar, Habajahan) の首長以外は商品を運べないこと を取り決めたという [Hikajat, 1896 ; James, $1902: 138$ 。

イブラヒムはしばらく滞在した後, パッサリブの首長達に彼が海岸に住むべき土地 を拽していることを話した。首長達は彼に協力を申し出た。イブラヒムはパッサリフ の四氏族の首長達を連れて出発した。

一行は, 海岸部に出た後,さらに旅を続け，ムフラニパンガナン (Muara Panganan）の地に到着した。そこの水を量ってみたところ，持参した水と同じ重さであっ た。イブラヒムは，この地こそが住むべき地であると判断し，町造りを開始した。そ して，その地を故鄉の地名バルス（Barus）にちなんで，バルスと命名した(6)。ま た同行して来たパッサリブの首長達に，その地に居を構えることを告げるとともに， バルスとパッサリブの相互防衛を彼らと誓い合った [Tambo, $1872: 20$; Drakard, 1988 : 205]。イブラヒムはこの町の初代の王となり，町はやがて繁栄し始めた。

故郷と同じ土の重さの地を求めて新たな居住地を捜すといら話は，ミナンカバウを 始め他のスマトラ地域の伝承にしばしば登場する [Westenenk, $1913: 235$; Nota, 1909: 555]。イブラヒムが，タルサンの水に含まれる土の重さと同じ重さの土をムア ラニパンガナンに見出したといら話であるが，ここで重要なことは，初代の下バルス 王となるイブラヒムが，バルスにやって来る前に，内陸部のトバ地区でその存在の正 
東南アジアー歷史と文化一 No. 22, 1993

当性を認められ，自らをパッサリブ氏族の一員と称している点である。パッサリブ氏 族の始祖サリブラジャ(Sariburaja) は，ラジャニウティとなったラジャニビアクビ アクの弟であった [Hoetagaloeng, $1926: 29$ ]。年代記の中でイブラヒムが任命した シリンドゥンの四代官やハッゥカラの彼の代理シンガニマハラジャは，その後定期的に バルスの沖に住むとされたラジャニウティに貢物を届けるため下バルス王を訪れた。 トバ族は，その貢物を下バルス王がラジャニウティに届けてくれるすのと考えた [Vergouwen, $1932: 552]$ 年代記でイブラヒムの残した，馬を奉納に来るようにと いら命令は，トバ族の外界の神聖王信仰を基盤にして正当化されたものであったので ある。パッサリブ地方の人々もまた，下バルス王をラジャニウティと彼らとの仲介者 とみなし，尊崇した [Marsden, $1811: 375]$ 。

こうして形成された下バルス王家とバタック族との緊密な関係は，バルとパタッ ク地区との交易活動を活性化させた。イブラヒムが立寄ったとされるシリンドゥン， パッサリブは，安息香の産地であった。先のピレスの記録のみならず, オランダ東イ ソド会社と下バルス王家が1668年に契約を結んだ後も，多量の安息香がこれらの地域 の人々によって搬出されたことが記録されている[VOC $1272: 1067]$ 。゚ッサリブ= ドロックのシパトゥバトゥに設けられた市場は, 産品の集荷場であったのである。そ こから，パッサリブの四氏族に属する人ふがバルスにまで商品を届けた。下バルス王 家は，その道中の安全を保障しこのネットワークは20世紀初めまで存続した [Ypes， $1932: 524]$ 。

バルスが安息香の産地の人々を動員し続けるためには，また同時に内陸部の食糧供 給を保障せねばならなかった。バルスの交易の隆盛は，パッサリブやシリンドゥンに 従来以上の安息香の搬出を求めることを意味した。それは, 産地に山岳部での安息香 の採集や栽培に従来以上の労働力をさかせることであり, 食糧生産に充てる労働力の 減少を招きかねなかった。食糧生産地としてみた場合, パッサリブやシリンドゥン周 辺のトバ高原はさほど米作に適した地ではなかった [Joustra, 1910 : 299 ; Adamse, $1913: 14]$ 。これらの産地への食糧供給を十全にできないバルスにとって, 安息香交 易を維持するためには内陸部の米作地带とネットワークを形成することが必須であっ た。

この意味で重要なのが，ハッカラである。年代記は，イブラヒムの息子とされるシ ンガ = アハジャがバタック族の王として君臨する場所としている。バッカラは, シ リンドゥンやパッサリブと異なり, 安息香の産地ではなかった。この地は, トバ湖に 注ぐ河川が形成した渓谷盆地であり，バタック地区でも有数の水田地帯であった。 
イブラヒムがバタック地区に打ける彼の代理と定めたシンガ=マハラジャは，トハ 族の間で農耕の豊穣を司る神聖王シンシンガニマンガラジャ（Si Singa Mangaraja） として尊崇された。バタック地区のほぼ中央部に位置するバッカラは海岸部の言語 (マレー語) や宗教 (イスラム教) の影響を受けにくかった地域である。このことは年 代記の中で, イブラヒム一行とバッカラの人々が最初言葉が通じなかったことや，人 人がイスラム教に改宗することを拒否したことにも示されている。トバ族は，シ＝シ ンガ = マンガラジャの生誕をイブラヒムの息子としてではなく，ヒンドゥ教と精霊崇 拝とを統合したバタック族の宗教観念に基づいて以下の如く表現している。

バッカラに伝わった伝承によれば [Pleyte, 1903 : 1-15], この地の一首長トガ = ハッカランシノンバ=デバタ（Toga Bakkara Sinomba Debata）は，結婚して 3 年 経っても子供がなかった。妻がある日水浴をしていると, 天から沙羅双樹（jambu barus）の実が降って来た。妻はその実を拾って食べたところ，身籠った。不思議に 思ったトガニバッカラが霊媒師に相談したところ, 沙羅双樹はバタラングルの化身で あり，それによって妻が身籠ったことを知られた。子供が生まれる際には，地震が起 こり, 豪雨となり, 嵐が起こり, 精霊達が村の原野をらろらろし, 虎や豹があばれま わり，稲妻が落ちることとなろうと告げられた。間もなく，天界の燕（バタランクル の使者) から, 出自, 作物の植え付け, 法規, 暦法, 容量の単位等を記した書付が, 卜 ガニハッカラに託された。そして，その子をシンガ=マンガラジャと命名し，代々そ の名を継承するよら告げられた。それから 7 年後, 予告された通りの非日常的状態の 中で，その子は生まれた。シニシンガニマンガラジャ生誕に関するバタック族の伝承 は他にも多少内容の異なるものが存在するが, 彼を至高神の息子バタラングルの化身 とみなす点では, 大体一致している [Heine-Geldern, $1959:$ 369-370]。

そして，稲作地帯に君臨するこの神聖王は，農耕を司る力を有するものとみなされ た。トバ族の伝承は，彼が生まれつき，稲やウビの生育を司ることができ，また雨を 自由に降らせることがでさたり，泉を掘り当てたりする能力を有していたとしている [Beck, $1917: 452-453$; Joustra, $1926: 218$; Helbig, $1935: 91-92$; 大林, 1985 : 165-166]。トバ地区の各地で, シニシンガニマンガラジャは供儀祭司パルパリギン （parbaringin）を任命した。このパルバリギンは，毎年農耕を開始する前に，氏族の 祖霊や水を司る神霊に供犠を捧げ，豊穣と子孫の繁栄を祈願した。

そしてこの供儀のための儀礼共同体の形成が，そこでの市場の開設としばしば連動 した。トバ地区では, 供儀儀礼共同体（ビウス bius）の名称が，市場の名称と重複す ることが多かったのである。トバ湖畔やトバ高原，シリンドゥンには，こうした市 
東南アジー一歴史と文化一 No. 22, 1993

場・供犠儀礼共同体の形成にシニシンガニマンガラジャが関与したといら伝承が存在 した [Ypes, $1932: 302,371,389,437]$ 。バルス一安息香産地の交易活動を支える, 内 陸部の食糧供給ネットワークが形成されたのである。

こらした農耕を司る後背地の権威を上バルス王家も必要とした。 バルスには, 下バルス王家の上流部に上バルス王家が存在した。上バルス王家に层 わる年代記は，一族が元来トバ湖畔のバリゲ (Balige) のポハン (Pohan) 氏族の出 身であり, トバ高原のドロック=サングル (Dolok Sanggul) やダイリ地区, さらに はバルスに近接するランベ (Rambe), トッカ（Tuka）に勢力を扶植した後，バ スにやって来たことを伝えている [Drakard, 1988 : 123-135]。トバ高原は安息香を， ダイリ地区は竜脳を産出する。後のオランダ東インド会社の記録によれば，上バルス 王の命により上記の地域より安息香や良質の竜脳がもたらされたことが伝えられてい

る $[$ VOC $1290: 600]$ 。

だが, トバ高原やダイリ，トゥカの諸地域もあまり食糧生産に恵まれた地域ではな かった。バルスに近接したトゥカの人々は，米をバルスの市場に求めた [Verslag, $1917: 198]$ 。このバルスで売られた米は，トバ地区とニアス島よりもたらされたもの であった。その他トバ高原やダイリ地区は，米が不足した場合には，トバ湖畔やシリ ンドゥン盆地から米を購入した [Adamse, $1913: 14$; Verslag, $1917: 259$ ]。こち した状況を反映して，ダイリの主要な竜脳の産地であったカラサン (Kalasan) やク パス (Kepas) では, シニシンガ = マンガラジャへの信仰が篤かった [Ypes, 1907 : $356,472]$ 。

従来の研究は, 初代シ =シンガニマンガラジャの登場を, 下バルス王家の成立と連 関させて，16世紀の初めから中葉としている [Heine-Geldern, 1959 : 393 ; Joustra, 1926 : 215]。その起源を歴史的に確定することは困難であるが，バルスが港市として 隆盛するためには，こうした内陸部の豊榱を司る権威が必要であったのである( 7 )。 シニシンガニマンガラジャは, 通常の説では初代から12代まで，すなわち1907年 6 月 に最後のシニシンガ =マンガラジャがオランダ軍に殺されるまで，バッカラを中心に バタラングルの化身として君臨した。

\section{N スマトラ東岸の港市と後背地}

バルスが内陸部の豊穣を司る権威と関係を形成した事情は，スマトラ東岸の港市と 後背地についても当てはまることであった。

先にも触れた如く，フチェは16世紀前半のスルタンンアランウッディン=リアヤッ 
北スマトラにおける港市国家と後背地

トニシャニフルニカハル (Sultan Alau'd-Din Ri'ayat Syâh al-Kahar) の時代から 17世紀前半のスルタン=イスカンダルニムダ（Sultan Iskandar Muda）の時代にか けて，スマトラ東西両海岸地域に执いて勢力を払大し，要衝に代官（panglima）を 任命した [Kathirithamby-Wells, $1969: 458-460$; Lombard, $1967: 25-26$ ]。その ため東岸においては, パサイやタミアン (Tamiang), アル（デリ）等がその影響下 に入った。

そして更にアチェは，これらの港市に産物を搬出した内陸部に存在したナグール王 国と抗争するに至り，これを解体させ，代ってデリの後背地のカ口地区，シマルンク ン地区を影響下に置いた。そしてカ口高原のリンガ (Lingga)，バルス (Barus Jahe), スカ (Suka), サリネンバ (Sarinembah) と, シマルンクン地区の シロ (Silo), パネ (Pane), シアンタル (Siantar), タナニジャワ (Tanah Jawa) にそれぞれに「四首長」(Raja Perempat [カロ], Raja Na Opat [シマルングン]) を任命した [Westenenk, a : 1-5；Joustra, $1910: 196$; Westenberg, $1914: 464$ ； van Dijk, 1894 : 171-172]。

カロ高原の四首長の存在した地域は, シバャック (Sibayak) 山, シナブン（Sinabun）山のふもとの盈地位置し、デリやランカットへの交易路が形成されていた 他, 西岸のシンケルに注ぐラウニレヌン (Lau Renun) 河沿いKダイリ地区とす絡 がった。シマルングンは，トバ湖と東岸港市とを結びつける位置にあり，東岸へはな だらかな斜面で絡がっていた。これらの内陸部から東岸港市へ16一18世紀に搬出した

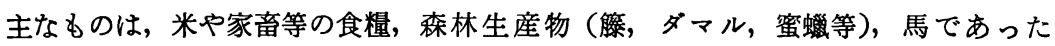
[Pires, $1966: 272-274$; Anderson, $1971: 247-297$; Joustra, $1910: 285-296]$ ]

首都バンダニアチェに多大な人口をかかえたアチェにとって，ペディール，パサ イ、デリの後背地は重要な食糧の供給地となった。17世紀前半及び中葉にデリから は，毎年400トン前後の米がアチェへ輸出されていた [Ito，1982:35-37]。海岸平野 からカロ高原に至るドゥスン (Dusun) と呼ばれた地域, 四首長の存在したカ口高原 の渓谷盆地, さらにはトバ湖畔が, 米を搬出した主要な産地と考兄られる。

このためアチェにとっても, バタック地区の農耕を司る権威は重要であった。バタ yク族の伝承は，この時期シ ニシンガニマンガラジャを始め，同様に豊楥を司るとみ なされた内陸部の権威が存在した話を伝えている。サモシール島の峡谷盆地のウラト (Urat) に君臨したオンプ=パルティ (Ompu Palti), プスックンブヒット山のふる とのサガランリンボン (Sagala Limbong) 盈地に君臨したジョンギニマナオル (Jonggi Manaor）がそれである。彼らは，19世紀後半においても豊楥をもたらす神聖王 
東南フジフー歴史と文化一 No. 22, 1993

として人々の尊崇を集めた [van Dijk, 1895 : 298 ; Ypes, $1932: 177$ ]。彼らもシ= シンガ = マンガラジャ同様, 港市の交易活動を補完する役割を有し，オンプニパルテ 1はその出身者にサモシールが多いシマルングン地区と関係を有し [Tideman, 1922 : 53, 59 ; Nota, 1909 : 554-555]，ジョンギ=マナオルはバルス（とりわけ下バルス 王家）と関係を有した (8)。したがって，時として彼らの間で内陸部の権威中权の座 をめぐり競合することがあり得たのである。

カロ族やトバ族は，この中でシ =シンガニマンガラジャがアチェのスルタンよりそ の王権を認められることで，彼らとの競合に優ったとみなした [Neumann, 1926 : 25, 27 ; van Dijk, 1895 : 300]。トバ族の伝承によると [Pleyte, $1903: 15-17$; Singa Mangaradja, 997=540 : 11-14 ; Tobing, 1967 : 33-37], シニシンガニマンガラジャ 1 世は賭博好きであったが，ある時敗れてしまい貧しくなり，彼のおばの嫁いだウラ トのオンプニパルティのもとを訪れ，援助を請うたという。トバ族の慣習は，嫁を与 えた側の一族に対し，嫁ぎ先の一族は敬意をもって対処せねばならないとしていた [Vergouwen, 1964:54]。だが，彼は括ば夫婦より冷たくあしらわれた。シンシンガ =マンガラジャは, 「貴方は, 私の霊力も神々も祖霊も恐れないのか」と尋ね返す と，おばは「ただボンガロン (Bonggaron) 象を恐れるのみである」と答え，彼を追 い帰した。

この話に登場するボンガロン象は，カロ高原に居住したシムビリン (Simbiring) 氏 族がアチェのスルタンに奉納したと伝えられる「白象」(Gaja Putih) のことである [Neumann, 1926 : 24-25 ; Westenenk, a : 3-4 ; Tideman, $1922: 71]$ 。これを受け 取ったとき，スルタンは大そう喜こんだという。

そこでシ =シンガ=マンガラジャは, この象を手に入れるため, 誰も人々が訪れた ことのなかったラジャニウティのもとを專ねたという。ラジャ=ウティは, シニシン ガニマンガラジャが本当に神の子かどらかを確かめるため，種々の難問を課した。そ れに対し，自らの超自然的能力を用いてその難問を解決するシニシンガニマンガラシ ヤを見て，ラジャニウティは彼が至高神の息子バタラ=グルの化身であり，バタック の王たる人物であることを認めた。そして, ボンガロン象の他王権を示す宝器を彼に 授けたという。ボンガロン象を得たシニシンガニマンガラジャは, トバに帰還し, 象 を用いておば夫妻の村を隇亡させたという。

トバ族はこのラジャニウティを, アチェのスルタンのことであるとしている [Hoetagaloeng, $1926: 30$; Ypes, $1932: 27]$ 。実際シニシンガ=マンガラジャは, アチェ のスルタンより授与されたサーベル（Gaja Dompak）や印を代々所有していた [van 
Dijk, 1895 : 301 ; Sidjabat, 1982 : 105-106]。また史実としてアチェの戦闘用象はス ルタンの軍事力の重要な部分であり，これを用いてイスカンダルニムダはアルを隇亡 させたのであった [Milner, McKinnon and Tengku Luckman Sinar, 1978 : 18]。 アチェのスルタンよりその権威を承認されることで, シニシンガ ニンガラジャは, オンプニパルティやジョンギニマナオルとの競合に優るとともに，シマルングンやカ 口地区の四首長達よりも尊崇されることとなったのである [Tideman, 1922 : 36-37 ; Neumann, 1926 : 25, 27 ; van Dijk, 1894 : 180-181]。

こらして形成された港市と後背地との関係は,アチェの勢力が後退した後も継続し た。アチェは，イスカンダルンムダの時代に全盛期を迎えた後，17世紀後半には影響 力を後退させ，東岸には代ってタミアン，ランカット (Langkat), デリ，セルダン (Serdang)，バトゥバラ(Batubara)，アサハン (Asahan) の港市国家の成立を見た。 しかし，港市と後背地との関係は，アチェの隆盛時代に形成されたものを継承した。 デリからカロ高原に至るドゥスン地区には, かつてフチェのスルタンによりカロ高原 と同様に四氏族の首長が任命されているが，デリのスルタンもこれを継承し，スンガ ル (Sunggal), ハンペラン=ペラ (Hamperan Perak), スカピリン (Sukapiring), スヌンバ (Senembah) のバタック族出身の首長をダトゥ（datuk：「頭目」）に任じた [Westenberg, $1914:$ 458-459]。彼らダトゥの役割は, ドゥスンに居住するカロ族と ランカット，デリ，セルダンの港市支配者とを仲介することであった。またカロ地区 とシマルングン地区に任ぜられた四首長は，その代が替わるごとにアチェのスルタン からその権威を承認されたデリのスルタンにより，その権威を保障された [van Dijk, 1894 : 179 ; Netscher, $1864: 348]$ 。

さらにアサハンもバタック族にとって重要な港市となった。アサハン王家は,イスカ ンダルニムダによってその王権を承認されたという伝承を有した [Westenenk, c : 1-10 ; Kroesen, $1886:$ 83-91]。王家の年代記は，イスカンダルニムダの子供を宿す パネイ (Panei) の王女を妻として与えられたバタック人のシバャクルンガ (Sibayaklengga）が，その子をアサハンの王とすることがアチェより認められた，としてい る。やがてスルタンの血を有する子アブドゥルシジャリル (Abdul Jalil) が生まれ, アサハン川河口のタンジュンニバレイ (Tanjung Balei) に王宮を構えることとなっ た。その際, アサハン川中流域のバンダル =プロ (Bandar Pulo) 周辺に川上と川下 の人々とが交易を行らための市場（bandar）が設けられたといら。

ハシンダル =プロはその後, トバ族が米や家畜, 森林生産物等を持ち寄る重要な市場 となった。その他シラウ (Silau) 川中流域に位置したバンダルニパシル =ムンドグイ 
東南アジー歴史と文化一 No. 22, 1993

(Bandar Pasir Mendogei), アサハン王家の分家クアル (Kualuh) が統轄したクア ル中流域のバンダルンマニス（Bandar Manis）も，同様にトバ族が東岸に産品を搬 出する市場となった [van den Bor, 1869 : 394-395 ; van Dijk, 1892 : 500-501]。 タンジュンニバレイはそれらを集荷する場所となったのである。

こうして東岸港市と後背地との関係が再構築される中で, シニシンガ =マンガラジ ヤの役割も継続した。とりわけデリやセルダン，バトゥバラとトバ湖畔とを絡ぐシマ ルングンの首長にとって, この神聖王の存在は重要であった。この地の四首長はシ = シンガ マンガラジャが訪れた際貢物を奉納する摜行を有し，それが最後のシニシン ガニマンガラジャの代まで存続した [Tideman, $1922: 36-37]$ 。またトバ地区とアサ ハンとが上述した市場を通して交易関係を形成したのに対応して，シニシンガニマン ガラジャは，トバ湖畔からアサハンヘ至るルートの要衝シトラン (Sitorang) の地に, 彼の代理としてシニジョラット（Si Jorat）を任命した [Helbig, 1935 : 92 ; mailr. 2674/1929 ; Indischen brief, 29/12/1892/no. 2453/3]。アサハンとトバとの間で係争 が生じた際，両者はしばしば仲裁に当たったのである。歴代のシニジョラットは, ト バ湖畔やアサハンの人々からシ = シンガ =マンガラジャ同様の超自然的力を有する存 在としてて尊崇された。

こらした港市と後背地との関係は，18世紀終りにペナンを中心とする交易圈が活性 化したとき，より強化された。18世紀末から19世紀後半までの北スマトラの主要な交 易相手は，ペナン，シンガポールなどのイギリスの海峡植民地であった。スマトラ東 岸のタミアン，ランカット，デリ，七ルダン，バトゥバラ，アサハン，シアク等の交 易活動は活発化し, 内陸部から森林生産物, 米, 家畜の他, 胡椒, タバコ, ガンビー ル等の商品作物や奴隷が輸出され, 輸入品も海産物や綿布, 金属製品の他, 阿片が重 要な商品となった [Anderson, $1971:$ 191-357 ; Dobbin, 1983 : 91-95]。

港市付近のバタック族の中には，胡椒やタバュの栽培に従事する者が生じた。1823 年スマトラ東岸を訪れたペナンのイギリス東インド会社社員のアンダーソンによれ

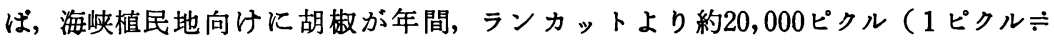
$62.5 \mathrm{~kg}$ )，ブル=チナ（Bulu Cina : デリ近郊）から約15,600ピクル，デリより約 26,000ピクル，セルダンより約 8,000 ピクルが輸出されたことが報告されている[Anderson, $1971: 246,260,279,304]$ 。その他，タバュやガンビール等の商品作物の輸出 についても報告されている。

17 世紀前半・中葉にはアチェに対し年間400トン前後の米の輸出を可能にしたデリ は, アンダーソンの記録では, その生産が住民の必要量をかろらじて賄う程度となっ 
ている。またそこに記録されているカロ高原やシマルングン地区からの輸出品は, リ ンガ (カロ高原) より胡椒, ガンビール, 馬, 蜜蠟, 象牙, タナニジャワ（シマルン クン）より，金，蜜蠟，象牙，綿花，タバコ, 奴隷, シアンタル（シマルングン）よ り蜜蠟, 象牙, 綿花, パルス, タバュ, 奴隷, 馬となっている [Ibid. 296-297]。こ こにも特に食糧の輸出は記されておらず，かわってガンビール，タバュ，綿花等の商 品作物が搬出されたことが報告されている。アンダーソンは，デリが不作の場合は米 を他地域より輸入することを述べている [Ibid. 276]。こうした状況は, 焼畑耕作の らちにガンビールやタバュ，綿花の生産を行なっていたカロ高原やシマルングン地区 の場合も同様であったと考えられる。

デリに近接した地域で米の輸出が記録されているのは，アサハンとランカットであ る。ランカットは内陸部と広範な交易網を有し, 後背地のカロ地区のみならず, トパ 湖畔の人々とも取引を行ったことが記されている [Ibid. 250-251]。またアサハンの 米は,アサハン川やシラウ川流域で生産されたものと, トバ湖畔で産出されたものの 双方が集荷されるため, 量的に多かった。後に1863年以降デリにタバコのプランテー ション栽培が導入された後も，アサハンはデリの主たる食糧の供給源の一つであっ た [Schadee, $1919: 217]$ 。

こうしてトバ地区は, 港市周辺での商品作物栽培が進展する過程で重要な食糧の供 給地となった。カロ地区においても，それまでアチェのスルタンより権威を保障され たが故にその存在を認められていたに過ぎなかったジシンガニマンガラジャが，こ の時期内陸部の豊嬢を司るが故に重要になってくる。胡椒栽培の盛んであったブル = チナのハンペラン =ペラの首長が，19世紀始めマレー化する䟢に，その出自をシ = シ ンガ=マンガラジャの一族と結びつけている [Westenenk, b : 1 ; Milner, $1982: 88$ ] ことや，19世紀後半のヨーロッパ人のドゥスン地区の踏㚗記録の中に，シ＝シンガ = マンガラジャ崇拝が登䬗する [de Raet, $1875:$ 184] ことは,この表われと言えよ ら。またアサハンに近接した後背地では, オランダ植民地支配の確立した後の 20 世紀 初頭においても, 依然としてシニシンガ = マンガラジャが不老不死の存在として, 至 高神ムラジャディニナニボロン，バタラニグルと並んで尊崇されていた[Aanvullings, $1911: 389]$ 。

\section{$\mathrm{V}$ 後背地の豊楥と権威中枢}

港市の活動が内陸部の農耕を司る権威と連動するとき, 海洋世界の隆盛は同時に内 陸部に彼らの生産活動を豊穣に導くための宗教文化を形成せしめることとなる。 
東南フジフー歴史と文化一 No. 22, 1993

シニシンガ = マンガラジャを始め, オンプニパルティ, ジョンギニマナオルいずれ あが，豊穣を司るとされた祖霊 (sombaon) の宿る山々へ供犠を捧げる儀礼に関係し た。トバ湖周辺には，既に紹介した人類発祥の地とされたプスック =ブヒット山の 他, ドロックントロン (Dolok Tolong : バリゲ), シボルボラン (Siborboran : サモ シール島), ドロックンパゥン (Dolok Paung : トバ高原), ドロックンイムン(Dolok Imum : トバ高原), シアタスニバリタ (Siatas Barita : シリンドゥン) 等の山タが 存在した。人々は, これらの山々を彼らの氏族の祖霊の宿る聖山であるとみなした。

シニシンガニマンガラジャやオンプニパルティは, 彼らの影響力を有する地域にパ ルバリギンと呼ばれた供敾祭司を任命した。彼ら祭司は，毎年農耕を始める前にこれ ら聖山の祖霊に対して豊穣と子供の繁栄を祈願して供犠（水牛）を捧げた [Korn, 1953 : 32-51 ; 97-127 ; Ypes, $1932: 153-189]$ 。たジョンギ=マナオルは, サガラ ンリンボンにてプスック =ブヒット山への供儀祭を司った。

その供儀祭において，いずれの聖山もプスック=ブヒット山となり，地上世界の創 造が儀礼の中で再現された。そしてプスックンブヒット山より外界に去りラジャ＝ウ ティとなったラジャニビアクビアクの霊 (Ompu Raja Baganding Tua と呼ばれた) と，同じくその山よりトバ湖に移ったとされた水界を統べる神ボル ルサニアンンナ ガ (Boru Saniang Naga) の霊が呼び出され, 人々に安寧と繁栄をもたらすよう祈 願された [Ypes, $1932: 187-188$; Korn, 1953 : 121-122]。農耕にとって重要な水と 外部世界の力とがプスックンブヒット山を通じて結びつけられたのである。バタック 族の間で,アチェのスルタンや下バルス王もしばしば稲やウビの生育を司る力を有す る存在として了解された [Neumann, 1926: 25 ; Tambo, $1872: 10,12$ ]。それは, これら港市支配者がラジャニウティの具象化したもの，あるいはこの神聖王との仲介 者とみなされ，ラジャニビアクビアクの霊と結びつけられて考えられたからである。 シニシンガ = マンガラジャの下バルス王やフチェのスルタン訪問も, こうした信仰に 基づいたものであった。

バタック族は，決してマレー，イスラム文化の影響に無縁たっったわけではない。19 世紀前半における東岸港市の隆盛は, 付近に居住するバタック族の中よりイスラム教 に改宗する者を生ぜしめた [Milner，1982:87-89]。またより内陸部のバタック族も それ以前よりイスラム教と接していた。その結果トバ族は, マリム (malim), ソラ ム (solam) といったイスラム教の用語を掫取し，ラジャニウティをマリムニニ=デ バタ (Malim ni Debata「神聖なるもの」), 彼のいたプスック =ブヒット山をタノ= ソラム（tano solam「聖地」）と呼び, シニシンガ = マンガラジャや至高神ムラシ 
北スマトラに扣ける港市国家と後背地

+ディニナニボロンに対し，ナ=ピトゥ=ハリ=マリム，ナ=ピトゥニハリ＝ソラム (na pitu hali malim, na pitu hali solam「七倍神聖にして, 七倍清い」)(9) と表現 した。だが,こらしたイスラムの用語の受容は, 彼らが従来の宗教信仰を捨てイスラ ム化することとは直接結びつかず，むしろ彼らの従来の神観念をより高度に表現する ための手段を提供することとなった。

また港市支配者も, 内陸部の権威中枢に対してイスラム教やマレー文化を受容する ことを強要しなかった。シニシンガニマンガラジャは，下バルス王家の伝承によれ ば，イブラヒムとイスラム教に改宗したバッカラの首長との間にできた息子となって いるが，歴代のシニシンガニマンガラジャはバタック族にとっては，バタラニグルの 化身であった。またアチェのスルタンも，シニシンガニマンガラジャの王権を認める に際し,イスラム教徒となることを強要しなかった。むしろ彼ら港市支配者も, 後背 地との関係を強める中で, バタック地区において影響力を行使できる存在を必要とし たのである。

シニシンガ = マンガラジャやカロ, シマルングンの四首長, シリンドゥンの四代官 達は, 港市と内陸部とのネットワークの維持につとめた。シニシンガニマンガラジャ やシリンドゥンの四代官, ジョンギニマナオルは, 定期的に下バルス王家を訪れ， ラ ジャ =ウティ宛の貢納を届けた。このことにより，トバ地区とバルスとの関係は，前 にも触れたよらにオランダ植民地支配の確立する20世紀初頭まで維持された。またシ シシンガ = マンガラジャはアサハンのスルタン, 並びにシマルングンの四首長を通し てデリのスルタンとも良好な関係を形成し，19世紀に入るとこれら東岸港市がバタッ ク地区と外界との重要な接触口となった[Anderson, 1971 : 146-147; de Scheemaker, 1869 : 476 ; mailr. 648/1885]。シニシンガニマンガラジャや彼によって任ぜられた パルバリデン, 四首長, 四代官達は, 各々の地域の係争を調停する役割を担った。ま たバタック地区における市場での平和は, たとえ部族戦争中においても維持されねば ならないとされた。

一般に17世紀後半から19世紀初頭までのバタック地区と周辺港市との関係は, 比較 的安定していた。この時期シニシンガニマンガラジャはさほど大きな権限を行使する 必要がなかった。そのため, 初代シニシンガニマンガラジャに関する伝承の多さに比 し，第二代目以降最後から三代目のオンプ ナーボロン（Ompu Na Bolon : 19世紀 始め在位)に至るまでの神聖王については，あまり多く語られていない。

だが19世紀初めになり，スマトラ東岸と海峡植民地との交易活動が活性化すると， シニシンガニマンガラジャの役割は再び重要になった。前節で述べたその豊稞を司る 
東南アシアー歴史と文化一 No. 22, 1993

力が再評価されるとともに，東岸港市を通してのバタック族の奴隷輸出の増加がトパ 族の誘拐を多発せしめるよらになったため，港市と後背地との安定的関係を維持する ことが求められたのである [Sidjabat, $1982: 83-98]$ 。シシンガ =マンガラジャや 彼の代理シニショラットとアサハンとの関係が緊密になったのはこの時期であった。 また西海岸においても，18世紀後半以降イギリス人商人の活動が活発となり，バルス 以外にもソルカム (Sorkam) やタパヌリ (Tapanuli), ナタル (Natal) における森 林生産物の輸出が盛んになった [Dobbin, 1983 : 171-172; Marsden, 1811 : 367374]。そうした港市の活動に刺激され，トバ地区のシリンドゥンは，19世紀初めタパ ヌリをもその主要な交易相手としていた [Verslag，1856:303]。新たな状況に対応 するため, シニシンガ=マンガラジャ（オンプ=ナ=ボロン）は，1824年イギリス人 と接触を持とうと試みた [Ward, H302；Raffles，1991：437]。

その後1820年代後半から1830年代前半に，ミナンカバゥ地区からパドリ (Padri) 軍団がバタック地区に侵入し，西海岸と内陸部とのネットワークを改編しようとした [Dobbin, $1983:$ 181-183]。オンプ=ナニボロンはこれに対抗し，パドリ軍団と戦闘 を交えた。これによりオンプ=ナニボロンは敗死したが，パドリ軍団のバタック地区 占領は短期間で終結し，既存の交易ネットワークの改編はならなかった。シンシンガ =マンガラジャの地位も存続し，神聖王にはオンプ=ナーボロンの息子オンプ =ソハ ファオン (Ompu Sohahuaon) が就いた。オンプ =ソハフアオンは，オランダが次第 にバタック地区南部やシボルガ (Sibolga)，バルス等西岸港市を影響下に置くのに対 応し, オランダ人やオランダ政庁に活動を認可されたドイッ人宣教師とる接触を持 ち，外部世界とバタック世界との安定的関係を保とらとした [Pleyte, 1904 : 468470 ; Meerwaldt, 1908 : 82 ; mailr. 801/1878]。

だが，バタック地区と周辺港市との関係は大きく変ろうとしていた。1863年以降ス マトラ東岸に拈いてタバのプランテーションが開始されると, 土地の貸与を通して 多大な収益が得られることとなった港市支配者が，次第に内陸部に対し，土地の領有 権を主張するに至る。またオランダ植民地支配が払大する中で，19世紀終りにオラン ダ政庁はトバ地区を労役と税制導入の対象として直接統治する方針を採ることとな る。15-17世紀に形成されたスマトラ島の港市と後背地との複合的ネットワークは, ここに大さな変容を余儀なくされ，内陸部の権威中权もその役割を喪失するに至るの である(10)。 


\section{，結 語}

本稿は北スマトラの港市と内陸バタック地区の事例を通して，15一-17世紀の海洋交 易活動の隆盛が，港市と後背地とのネットワークの強化をむたらし，その結果後背地 に，内陸部の生産活動を保障する権威中权が形成されるに至ったことを考察した。港 市の隆盛は後背地との関係をより強固にしたが，社会的文化的には，必ずしも前者の 後者に対する同化や一義的関係を形成するには至らなかった。バタック族のアチェや バルスの支配者に対する尊崇の念は，外界の神聖王ラジャニウティの故郷とされたト バ湖畔の聖山ブスックンブヒットに宿る祖霊と結びついていた。そして外界とバタッ ク世界とを仲介する役割を果したシンシンガニマンガラジャは，下バルス王スルタン =イブラヒムの息子とされ，かつアチェのスルタンより王権を保障されたにるかかわ らず，バタック族の間では豊櫰を司るバタラングルの化身とされた。

バタック族は，マレー・イスラム文化からまったく孤立していたわけではない。東 岸の港市付近のバタック族はイスラム教徒となり，マレー化したものもあった。また 内陸部のバタック族の中にも，イスラムの宗教用語を受容した者がいた。だがこれら は, 港市と後背地との関係の一側面であり, 総体的にみれば, 港市付近のマレー化に 対応して, 内陸部にバタック的権威の結実していく現象がみられ, 宗教文化的にはイ スラム教と接触することで彼らの至高神や聖山に対する観念をより高度に再構築した と言えよう。「伝統的」バタック社会を特色づけた宗教文化の重要な部分が，15-17 世紀の海岸部の動向に対応して形成されたのである。

15一-17世紀に隆盛したスマトラ島のアチェやパサイ, バルス, デリ，アサハン，シ アク, パダン, ジャンビ, パレンバン等の港市の後背地には, ガョ, アラス, バタ ック，ミナンカバウ，クブ，ルジャン, ランポン等の内陸部社会が存在した。両者は いずれも緊密なネットワークを形成した。一般に19世紀中葉に至るまでスマトラ島の 内陸部の人々は, 港市に搬出した産品の採集・栽培を, 彼らの焼畑及び氷田での生産 活動と併存させて行なっていた [Kathirithamby-Wells, $1992: 28-31]$ 。そこでは, 後背地の生産活動に関係する宗教文化や権威がしばしば保持され, 同時に沿岸部との 関係が形成されたのであった。従来, 海岸部之異なる内陸部の社会的文化的特質がし ばしばその環境の孤立性に求められた [Castles, $1979: 75]$ のに対し，本稿はそれ が沿岸港市との相互的関係の故に形成されたことを明らかにしょらとしたものであ る。 
東南アジフー歴史と文化一 No. 22, 1993

注

（1）ラジャ=ウティがバルスにいることについては異説があり，フタガルンはア チェへ飛んで行ったとしている [Hoetagaloeng, $1926: 30$; Ypes, $1932: 27$ ]。 が，ほとんどの伝承はラジャニウティがバルスへ飛んでいったとしている。後に 述べるが，アチェが16世紀以降スマトラ西海岸で影響力を払大するにつれ，「外 界」の神聖王ラジャニウティがアチェに存するといら伝承も登場してきたるのと 思われる (本稿 $\mathbb{N}$ 参照)。

（2）ただしカロ族とトバ族との言語的親縁関係はかなり薄く [Voorhoeve, 1955 :9], 歴史的にカロ族がトバ地区より払散したという確証はない。カロ族と近接す るガョ (Gayo) 族は, 彼らの祖先の一人がカ口地区に䔟住し, カ口族の始祖と なったといら伝承を有している [Bowen, $1991: 232]$ 。また歴史的にはアル (Aru) とカロ族との関係も考慮されねばならない[Milner, McKinnon and Tengku Luckman Sinar, 1978 : 19]。

（3）ピレスは，バルスがミナンカバウの要衝であるとしている [Pires, 1966 : 288]。下バルス王家の伝承によれば，初代下バルス王スルタン=イブラヒム (Sultan Ibrahim) はミナンカバウのタルサン (Tarusan) の出身であった。イ ブラヒムがバルスにやって来て町造りを始めたとき, 既に存在していた川上の上 バルス王家と一時緊張関係に陥った。そのためイブラヒムは, 上バルス王の求め に応じたアチェのスルタンに殺害されたとい5 [Tambo, 1872 : 16-23 ; Drakard, $1988: 202-208]$ 。

（4）ここで用いたものは，いくつか伝わる写本の中でも比較的オリジナルに近い ものと思われる，上バルス王家の年代記『バルス王統の由来』(Asal Keturunan Raja Barus [1853-1866年の間にオリジナル作成さる]) と下バルス王家の年代 記『トゥアンク ニハトゥニバタン[伝承上の初代下バルス王］史』（Sejarah Tuanku Batu Badan [1834-1872年の間にオリジル作成される]) である。両 年代記は，Drakard，1988に現代インドネシア語綴りにて表記したものが収録さ れている。この二つの年代記には，(1)後背地バタック地区との関係の樹立，(2) ルスにおける両王家の共存, (3)アチェやオランダよりその存在の正当性を認めら れていること, の三つのテーマが共通して存正している。バルスがオランダ植民 地支配に服した1839年前後あるいはそれ以降に作成された両王家の年代記の記 述には，オランダ支配下で王家の権威を保持しょうとして両家の意向が反映され ていると言える。それだけに（1)のバタック地区との関係の樹立に関する部分の 
記述は, 王家にとってもその影響力を主張する上で重要であり, 本稿のテーマに とって貴重な材料を提供してくれる。

（5）バタック族にとって，「獅子」(singa）は，人々を悪霊より守護する力を有 する存在として信ぜられ，支配者に対してもこの語を尊称として用いていたこと が，ピントの記述の中で，バタック王アンジェシリ＝ティモラジャがマラッカの ポルトガル人司令官に対して「獅子」といら語で呼びかけていることからるらか がえる [Pinto, 1979 : 37]。また「大王」(maharaja) の称号は, バタック地区 にはミナンカバゥ経由で入ったものと思われ，アル王の中にこの称号を用いた者 [Maharaja diraja] がいた [Milner, McKinnon and Tengku Luckman Sinar, 1978 : 13]。尚, イブラヒムのトバ地区での逗留を記した年代記の中では, イブ ラヒムはバタック族との関係に扣いて，「大王陛下」(baginda seri maharaja, seri paduka maharaja, seri maharaja) の語で表現されている [Tambo, 1872 : 10-13 ; Drakard, 1988 : 195-199]。

（6）バルスといら名称について，ピレスはその記述の中で，グジャラート人，ペ ルシア人, アラビア人, ベンガル人, タミル人はこの地をパンシュールと呼び, スマトラではバルスと呼んでいるとし，これらは一つの王国であって，二つの王 国ではないとしている [Pires, 1966 : 287-288]。16世紀以前にもこの地を指す 苸称としてパンチュール (Pancur), ファンスール (Fansur) がよく用いられて いた。尚,バルスといら地名は, 北スマトラの竜脳を産する地域一円を意味する 呼称として用いられていた可能性があり [Wolters, 1967:180], 現在のバルス にそれを同定させることのできる確証としては，ピレスの記述が最初である。フ フンスール（またはパンチュール）が現在のバルスの位置に同定できる記録は, 本文でる述べたように 9 世紀以降のアラビフ語の史料に登場する。

（7）その他, ミナンカバウのパガルルニン王によって任命されたといら伝承す存 在する [Verslag, $1856: 283-284]$ この場合も, バルスがミナンカバウの重要 な港市（金の輸出港）となった時期である。

（8）オンプ=パルティの起源については, シマルングンのタナ=ジャワのジャワ 出身の首長がかつてジャワからミナンカバウを経て, サモシール島のウラトの首 長のもとに滞在したといら伝承を有しており [Nota，1909: 554-555]，これと 関係した可能性がある。伝承は，アチェが勢力を確立する以前のことであるとし ている。ジョンギ=マナオルは, プスックンブヒット山のふるとの神聖王である ため, 起源的にはかなり古くから存在した可能性がある。下バルス王家の年代記 
東南アシシアー歴史と文化一 No. 22, 1993

は, 後年オランダ人と最初に接触を持つに至るトゥアンク ニ゙ジンジョン ( Tu. anku Bagonjong）がバタック地区を訪れた際, リンボンの地に彼の代理として ションギ=マナオルを任命したとしている [Tambo, 1872 : 35 ; Drakard 1988 : 219]。いずれにせよ, 彼らの存在が重要になってくるのは, 16・17世紀以降のこ とである。

（9）この「七倍神聖にして」の「七」は, トバ族の聖数で, 全体性 (完全)を意味 したっこの文句は,「この上なく最高に神聖にして」の意味である [Sinaga, 1981 :55-56]。

（10）オランダ植民地支配による北スマトラの港市・後背地ネットワークの変容に ついては, 拙稿 [弘末, 1992] を参照されたい。

引用文献

〈略号一覧〉

A.R.A. Algemeen Rijksarchief (The Hague)

Bijd. Bijdragen tot de Taal-, Land-en Volkenkunde

E.N.I. Encyclopaedie van Nederlandsch-Indië

I.G. De Indische Gids

K.I.T.L.V. Koninklijk Instituut voor Taal-, Land- en Volkenkunde

K.I.T. Koninklijk Instituut voor de Tropen (Amsterdam)

K. T. Koloniaal Tijdschrift

mailr. mailrapport

R.Z. De Rijnsche Zending

T.B.B. Tijdschrift voor het Binnenlandsch Bestuur

T.B.G. Tijdschrift voor Indische Taal-, land-en Volkenkunde

T.N.A.G. Tijdschrift der Koninklijk Nederlandsch Aardrijkskundig Genootschap

Aanvullings, 1911. "Aanvullings-nota van toelichting betreffende het landschap Asahan", T.B.G., vol. 53, pp. 385-410.

Adamse, C. J., 1913. "Memorie van overgave van de Onderafdeeling Toba", (in A. R. A. ).

Anderson, J., 1971. Mission to the East Coast of Sumatra in 1823, Oxford. 
Bataks, 1917. "Bataks", E. N.I., vol.1, pp.177-182, The Hague and Leiden. Beck, W. J., 1917. "Si Singa Mangaradja”, T. B. B., vol.53, pp. 450-457.

Bor, A.C. van den, 1869. “Bijdragen tot de kennis van Sumatra's noordoostkust", T.B.G., vol. 17, pp. 377-411.

Bowen, J. R., 1991. Sumatran Politics and Poetics: Gayo History, 1900-1989, New Haven and London.

Broch Onz, 93=542, “Onze vestiging te Baroes", n.d., (in K.I.T.).

Castles, L., 1979. "Statelessness and Stateforming Tendencies among the Batak before Colonial Rule". In Pre-colonial Statesystems in Southeast Asia, edited by Reid, A. J.S. and Castles, L., pp.67-76, Kuala Lumpur.

Dijk, P.A.L.E. van, 1892. "Nota over de landstreek in de Toba-landen, bekend onder den naam van Habinsaran", T.N.A.G., 2nd series vol.9, pp. 477-505.

1894. "Rapport betreffende de Si Baloengoensche landschappen Tandjoeng Kasau, Tanah Djawa en Si Antar”, T.B.G., vol.37, pp. 145-200.

1895. "Eenige aanteekeningen omtrent de verschillende stammen (margas) en de stamverdeeling bij de Bataks. Het priesterhoofd Si Singa Mangaradja, zijn ontstaan en zijne afkomst. Het eten van menschenvleesch bij de Bataks", T. B.G., vol. 38, pp. 296-315.

Dobbin, C., 1983. Islamic Revivalism in a Changing Peasant Economy: Central Sumatra, 1784-1847, Copenhagen.

Drakard, J., (ed.) 1988. Sejarah Raja-Raja Barus, Jakarta and Bandung. 1989. "An Indian Ocean Port : Sources for the Earlier History of Barus", Archipel, vol.37, pp.53-82.

1990. A Malay Frontier: Unity and Duality in a Sumatran Kingdom, Ithaca, New York.

Hall, K.R., 1977. "The Coming of Islam to the Archipelago : a Reassessment", In Economic Exchange and Social Interaction in Southeast Asia: Perspectives from Prehistory, History, and Ethnology, edited by Hutterer, K. L., pp. 213231, Ann Arbor, Michigan.

1985. Maritime Trade and State Development in Early Southeast Asia, Sydney and Wellington. 
東南フジフー歴史と文化一 No. 22, 1993

Heine-Geldern, R., 1959. “Le pays de P'i-k'ien, le Roi au Grand Cou et le Singa Mangaradja", Bulletin de l'École Française d'Extrême-Orient, vol. 49, pp. 361-404.

Helbig, K., 1935. "Der Singa Mangaradja und die Sekte der Pormálim bei den Batak", Zeitschrift für Ethnonogie, vol.67, pp. 88-104.

Hikajat 1896. "Hikajat katoeroenan radja di koeria Ilir", Ijzeren Kastlist 997 $=540$ (in K.I.T.).

Hill, A.H., 1960. "Hikayat Raja-Raja Pasai", Journal of the Malayan Branch of the Royal Asiatic Society, vol.33, part 2, pp.1-215.

弘末雅士 1992 「オンダ植民地支配とスマトラ社会一港市・後背地ネットワー クの変容」石井米雄, 辛島昇, 和田久徳編著『東南アジア世界の歴史的位相』: 153 -175頁所収, 東京 : 東京大学出版会。

Hoetagaloeng, W.M., 1926. Poestaha taringot toe Tarombo ni Bangso Batak, Laguboti.

Indischen brief 29 Dec. 1892, no.2453/3, in Verbaal 2/6/1893/112, (in A. R. A. ).

Ito, T., 1982. "A Note on Some Aspects of the Trade of Aceh in the 17th Century”, 『南方文化』 9 号, pp. 33-60.

James, K.A., 1902. "De geboorte van Singa Maharadja en het ontstaan van de koeria(district) Ilir in de onderafdeeling Baros”, T.B.G., vol.45, pp. 134143.

Joustra, M., 1902. "Mededeelingen omtrent, en opmerkingen naar aanleiding van het "pěk oewaloeh" of het doodenfeest der měrga Simbiring", T.B.G., vol. 45 , pp. $541-556$.

1910. Batakspiegel, Leiden.

1926. "De Singa Mangaradja-figuur", In Gedenkschrift voor het Koninklijk Instituut voor de Taal-, Land-en Volkenkunde van Nederlandsch-Indië, pp. 211-221, The Hague.

Kathirithamby-Wells, J., 1969. “Achehnese Control over West Sumatra up to the Treaty of Painan, 1663", Journal of Southeast Asian History, vol. 10, no. 3, pp. 453-479.

1992. "Socio-political Structures and the Southeast Asian Ecosystem : An 
Historical Perspective up to the Mid-Nineteenth Century", In Asian Perceptions of Nature, edited by Bruun, O., and Kalland, A., pp. 18-38, Copenhagen.

Kern, H., 1903. “Drawidische volksnamen op Sumatra”, Bijd., vol.55, pp. 358-362.

Korn, V.E., 1953. "Batakse offerande", Bijd., vol. 109, pp.32-51, 97-127.

Kroesen, C.A., 1886. "Geschiedenis van Asahan", T.B.G., vol. 31, pp. 82-139.

Kroeskamp, H., 1931. De Westkust en Minangkabau(1665-1668), Utrecht.

Lebar, F.M., (ed.) 1972. Ethnic Groups of Insular Southeast Asia, vol.1, New Haven.

Ligny, J. de, 1923. "Legendarische herkomst der kamfer Baroes", T.B.G., vol. 58, pp. 549-555.

Lombard, D., 1967. Le Sultanat d'Atjeh au temps d'Iskandar Muda, 16071639, Paris.

Macleod, N., 1905. "De Oost-Indische Compagnie op Sumatra in de 17e eeuw", I.G., pp. $470-486$.

mailr. 801/1878. Resident van Tapanoli, "Extract uit het verslag betrekkelijk de verwikkelingen in de Battaklanden en de daarop gevolgde militaire expeditie naar Toba", (in A.R.A.).

mailr. 648/1885. Resident van Oostkust van Sumatra aan Gouverneur Generaal van Nederlandsch-Indië, (Bengkalis, 28 Aug. 1885).

mailr. 2674/1929. Gobée, E. and van Lith, "Rapport omtrent Si Singamangaradja en zijn naaste familieleden", in Verbaal 14/10/1930/20.

Marsden, W., 1811. The History of Sumatra, London.

Meerwaldt, J.H., 1908. “De laatste Singamangaradja”, R.Z., pp.2-11, 81-88, 98-100, 113-120, 129-131.

Miksic, J., 1980. "Classical Archaeology in Sumatra”, Indonesia, no. 30, pp. 43-66.

Milner, A.C., 1982. Kerajaan: Malay Political Culture on the Eve of Colonial Rule, Tucson.

Milner, A.C., McKinnon, E.E., and Tengku Luckman Sinar, S. H., 1978. “A Note on Aru and Kota Cina", Indonesia, no. 26, pp. 1-42. 
東南アシアー歴史と文化一 No. 22, 1993

Netscher, E., 1864. “Togtjes in het gebied van Riouw en onderhoorigheden", T. B.G., vol. 14, pp.1-23, 340-351.

Neumann, J.H., 1926. "Bijdrage tot de geschiedenis der Karo-Batakstammen", Bijd., vol. 82, pp.1-36.

Nota, 1909. "Nota van toelichting betreffende de Simeloengoensche landschappen Siantar, Panei, Tanah Djawa en Raja", T.B.G., vol.51, pp.525-567.

大林太良 1985 『シンガ・マンガラジャの構造』, 東京 : 青土社。

ピント,メンデス 1979 『東洋遍歴記 1』岡本多希子（訳）東京：平凡社, (Rebello, J. I. de Brito(ed. ) 1908-1910. Peregrinação de Fernão Mendes Pinto, Lisboa). ピレス,トメ, 1966 『東方諸国記』生田滋, 池上岑夫, 加藤栄一, 長岡新治郎(訳 ・ 注) 東京：岩波書店 (Cortesão, A., (ed.) 1944. The Suma Oriental of Tomé Pires, London).

Pleyte, C. M., 1903. "Singa Mangaradja : de heilige koning der Bataks", Bijd., vol. 55 , pp. $1-48$.

1904. "Hoe de Bataks over wijlen Dr. H. N. van der Tuuk dachten", T. B.G., vol. 47, pp. 468-470.

Raet, J.A. M. van Cats Baron de, 1875. "Reize in de Battaklanden in December 1866 en Januarij 1867", T. B.G., vol.22, pp. 164-219.

Raffles, L.S., 1991. Memoir of the Life and Public Services of Sir Thomas Stamford Raffles, Singapore, Oxford and New York.

Reid, A.J.S., 1980. "The Structure of Cities in Southeast Asia, Fifteenth to Seventeenth Centuries", Journal of Southeast Asian Studies, vol.6, no.2, pp. 235-250.

Sastri, Nilakanta K.A., 1932. “A Tamil Merchant-guild in Sumatra”, T.B. G., vol. 72, pp. 314-327.

Schadee, W.H.M., 1919. Geschiedenis van Sumatra's Oostkust, vol.2, Amsterdam.

Scheemaker, L. de, 1869. “Nota betreffende het landschap Batoebarah", T.B. G., vol. 17, pp. 461-479.

Sidjabat, W. B., 1982. Ahu Si Singamangaraja: Arti Historis, Politis, Ekonomis dan Religius Si Singamangaraja XII, Jakarta.

Sinaga, A. B., 1981. The Toba-Batak High God:Transcendence and Immanence, 
St. Augustin.

“Singa Mangaradja”, Ijzeren Kastlist 997=540, n.d. (in K.I. T.).

Tambo, 1872. “Tambo asal-oesoel ketoeroenan Radja-Taroesan datang kenegeri

Baroes”, in V.E. Korn Collection, no. 436, (in K.I.T.L.V.).

Tideman, J., 1922. Simeloengoen: Het land der Timoer-Bataks in zijn vroegere isolatie en zijn ontwikkeling tot een deel van het cultuurgebied van de Oostkust van Sumatra, Leiden.

1936. Hindoe-invloed in noordelijk Batakland, Amsterdam.

Tobing, A.L., 1967. Si Singamangaradja I-XII, Medan.

Vergouwen, J.C., 1932. "Een Italiaan onder de Bataks", K.T., vol.21, pp. 547-560.

1964. The Social Organisation and Customary Law of the Toba-Batak of Northern Sumatra", The Hague.

Verslag, 1917. "Verslag van een reis van den controleur van Baros naar de beoosten Baros gelegen onafhankelijke landschappen in het jaar $1883^{n}, T . B$. B., vol. 52, pp. 195-205, 252-265.

Verslag, 1856. "Verslag van eene reis in het land der Bataks, in het binnenland van Sumatra, ondernomen in het jaar 1824, door de heeren Burton en Ward, zendelingen der Baptisten. Medegedeeld door wijlen Sir Stamford Raffles”, Bijd., vol.5, pp. 270-308.

VOC 1272. "Raport vanden ondercoopman en boeckhouder Johannes Melman wegens Baros (29 Aug. 1669)", pp. 1068-1088, (in A. R. A. ).

VOC 1290. "Rapport vanden ondercoopman François Backer wegens Baros etc. dato 31 Dec. 1671", pp. 595-605.

Voorhoeve, P., 1955. Critical Survey of Studies on the Languages of Sumatra, The Hague.

Vuuren, L. van, 1908. “De handel van Baroes, als oudste haven op Sumatra's Westkust, verklaard; en voor de toekomst beschouwd", T.N.A.G., vol.25, pp. 1389-1402.

Ward, N. M., H302, Ward to Michiels, (Padang, 19 Sep. 1846) (in K. I. T. L. V.).

Westenberg, C.J., 1914. “Adatrechtspraak en adatrechtspleging der Karo- 
東南アシシフー歴史と文化一 No. 22, 1993

Bataks", Bijd. vol. 69 , pp. 453-600.

Westenenk, L.C., 1913. “Opstellen over Minangkabau”, T.B.G., vol.55, pp. 234-251.

a, "Hasal moela-moela doeloe soepaja ada ra'jat di tanah Karo ini", in Westenenk Collection no. 44 (in A.R. A.).

b, "Jang menjalin ini hikajat Sutan Amat jang berpangkat wadjir di Sepoeloeh Doewa Kotta be gelar Datoek Setia Radja wadjir Sepoeloeh Doewa Kotta Hamparan Perak", in Westenenk Collection no. 44.

c, “Asahan", in Westenenk Collection no. 44.

Wolters, O.W., 1967. Early Indonesian Commerce: A Study of the Origins of Śrivijaya, Ithaca, New York.

吉田集而 1971 「北スマトラ Tapanuli 地方における安息香の栽培とその市場品」『東 南アジア研究』9 巻 3 号 : 420-446頁所収。

Ypes, W.K.H., 1907. "Nota omtrent Singkel en de Pak-pak landen", T. B. G., vol. 47, pp. 355-642.

1932. Bijdrage tot de kennis van de stamverwantschap, de inheemsche rechtsgemeenschappen en het grondenrecht der Toba-en Dairibataks, Leiden.

\section{Port Polities and Hinterlands in North Sumatra}

\section{HIROSUE MASASHI}

North Sumatra, a production base for precious forest and mineral products, played a significant role in international maritime trade from early centuries. Contacts with the outside world through trade helped to develop coastal entrepots exporting products from the interior. The linkage between the coastal port and the hinterland has been one of the central issues for scholars working on Sumatran maritime trade history and its political culture. The coastal port needed the hinterland for its products, and the hinterland needed the coastal port in order to barter products for necessities of salt and cotton cloths. Royal 
chronicles of Sumatran port polities often connect their raison dêtre with the support of hinterland peoples.

The 15-17th century activation of maritime trade in Southeast Asia reconfirmes the symbiosis between the two entities. During this period there appeared the prosperous coastal principalities of Aceh, Pasai, Aru and Barus in north Sumatra. In order to respond to increased demands by visiting merchants for forest and mineral products and also pepper, the coastal rulers needed to mobilize their hinterland peoples more effectively. The military superiority of the coastal principalities may have given them greater influence over their hinterlands. Nevertheless, for these principalities it was difficult to handle affairs in the interior consistently, and particularly to guarantee that the agricultural system would allow the people to collect and cultivate their products.

In this context the hinterland authority, which the interior people believed was associated with the fertility of their agricultural production, was regarded as a highly important figure to the coastal rulers. The Batak case of the rise of the divine king, Si Singa Mangaraja, in the Toba lakeside region of Bakkara from about the 16th century shows us one example of one hinterland counterpart to the prosperous coastal principalities of Barus and Aceh.

According to the royal chronicle of Barus Hilir (Downstream Barus), the Si Singa Mangaraja I was a son of Sultan Ibrahim, the first legendary king of Barus Hilir. Barus had been well-known as a forest products export harbour since at least the 9th century. Sixteenth century Barus became fairly prosperous as many Muslim merchants began to visit the west coast of Sumatra after the Portuguese capture of Malacca. Descriptions by Tomé Pires, who visited Barus in the 1510s, and by the Dutch East India Company, which established a factory there in 1668, show that a large quantity of the forest products of camphor and benzoin were brought to the port by the Batak interior people.

In order to mobilize the interior people to bring forest products, Barus needed to establish its legitimacy among them by associating itself with the hinterland authority, which was believed to insure their agricultural production. The place where the Si Singa Mangaraja resided was one of the most productive 
東南アジアー歴史と文化一 No. 22, 1993

hinterland sawah (wet rice cultivation) areas. Batak legends generally regarded the Si Singa Mangaraja as a reincarnation of Batara Guru and as having supernatural power to control the growth of rice and ubi, and the supply of the water which was essential to cultivation. There were successive Si Singa Mangaraja figures in Bakkara, constantly "reincarnated" until the last one (usually called Si Singa Mangaraja XII) was killed by the Dutch colonial army in 1907. Every Si Singa Mangaraja endeavoured to maintain stable trading relations between Barus and the hinterland. The power of these figures was also highly regarded by the people where Barus Hulu (another royal family of Upstream Barus) was influential.

Aceh and other coastal principalities in Sumatra's east coast also appreciated the existence of this Batak divine king.

From the period of Sultan Alau'd-Din Ri'ayat Syâh al-Kahar to that of Sultan Iskandar Muda, Aceh endeavoured to establish its hegemony over both the east and west coasts of north Sumatra. At the beginning of the 17th century, Aceh brought Tamiang, Deli and Asahan under its influence. To Aceh the hinterlands of these areas became important suppliers of rice because the people of its own hinterland were preoccupied with commerce and pepper cultivation. Aceh annually imported from Deli about 400 tons rice during the beginning and middle of the 17th century. The Toba lakeside became one of the important regions for rice export to the coast. The Batak people generally perceived that the Sultan of Aceh recognized the $\mathrm{Si}$ Singa Mangaraja as king of the Batak.

After Aceh's decline in the latter part of the 17th century, Deli and Asahan became the important outlets for the Batak people. The Si Singa Mangaraja was on good terms with the Sultan of Asahan and the major chiefs of Simalungun, who mediated the trade between the Toba area and Deli. After the trade around the Straits Settlement became active from the end of the 18th century, the cultivation of pepper, gambir and tobacco, which were exported to Penang, was begun among the interior people near the coastal principalities of Langkat, Deli, Serdang and Asahan. Their reverence for the Si Singa Mangaraja was renewed as they became more reliant on foodstuffs from the 
Toba lakeisde.

The Batak case suggests that the hinterland centre of authority was crystalized as the coastal principalities became prosperous. Although the royal chronicle of Barus Hilir claims that the Si Singa Mangaraja was a son of Sultan Ibrahim, the Batak people regarded him as a divine king based on Batak religious concepts which basically consisted of animistic beliefs and Hinduism. Coastal rulers of Aceh or Barus did not urge the Si Singa Mangaraja to become Muslim. Rather they needed a Batak divine king who could exercise his influence over the interior in order to maintain stable relations between the coastal principalities and the hinterland. The facts brought out in this study strongly suggests that previous explanations, which tended to interpret such hinterland societies as culturally different from coastal societies and closed to their influence, need to be reexamined. 